\title{
Fortellinger om gutters krise, jenters fremgang og skolens utfordringer med sosiale ulikheter
}

\section{Turid Skarre Aasebø}

Universitetet $i$ Agder, Norge

\section{SAMMENDRAG}

Gutter som skolens tapere er blitt en dominerende fortelling gjennom mange år og gjentas nok en gang gjennom Stoltenbergutvalgets rapport om kjønnsforskjellene i skolen. Fortellingen bygger på en dikotomisk kjønnsforståelse og ikke en forståelse av at kjønn er mangfoldig og konstrueres kontinuerlig i kulturelle, sosiale og språklige sammenhenger. Ved å betrakte gutter som skolens tapere som et dominerende narrativ belyser jeg premissene for en slik fortelling, konsekvensene den har og hvilke fortellinger som usynliggiøres eller stilles i skyggen - fortellinger om en skole som ikke evner å utjevne de sosiale ulikhetene den har et mål om å utjevne.

Nøkkelord: kjønn; kjønnsdiskurs; skoleprestasjoner; sosial utjevning; narrativer

\section{ABSTRACT \\ Narratives about failing boys, successful girls, and schools' challenges with social inequalities}

The narrative about failing boys in school has been the dominating narrative for years and is recently repeated in the Stoltenberg committee report about gender differences in school. The narrative relies on a dichotomic view of gender, not a diverse approach in which gender is continuously constructed in cultural, social and linguistic contexts. Considering failing boys in school as a dominating narrative provides possibilities to illuminate how this narrative works and consequences for the knowledge base in school and educational policy. The dominating narrative of failing boys makes another narrative rather invisible or overshadows the narrative about the school as unable to contend with the social inequalities it intends to contend.

Keywords: gender; gender discourse; school achievements; social equality; narratives

Mottatt: Februar, 2020; Antatt: November, 2020; Publisert: Mars, 2021

Kjønnsforskjeller i elevenes prestasjoner i skolen har fått bred oppmerksomhet etter Stoltenbergutvalgets rapport i 2019. Basert på data fra nasjonale prøver, Pisa-tester og karakterstatistikker slås det fast at gutter presterer dårligere enn jentene gjennom

\footnotetext{
^Korrespondanse: Turid Skarre Aasebø, e-post: turid.s.aasebo@uia.no 


\section{T. S. Aasebø}

hele utdanningsforløpet, bortsett fra på noen målinger og i faget kroppsprøving (NOU 2019: 3, s. 11,27). Utvalgets mandat har vært å «bygge et nyansert og balansert kunnskapsgrunnlag om hvorfor kjønnsforskjeller oppstår» og "gi et bedre grunnlag for å velge de mest effektive virkemidler og tiltak for å motvirke uheldige kjønnsforskjeller i skoleprestasjoner» (NOU 2019: 3, s. 27). Utvalget antar at kjønnsforskjellene bare vil fortsette å øke i fremtiden.

Kritikken av Stoltenbergutvalgets rapport har også vært omfattende. En innvending går ut på at en ikke kan se bort fra at utdanning betyr mer for jenters yrkesmuligheter enn for gutters. Mange tradisjonelle kvinneyrker forutsetter utdanning på høyere utdanningsnivå og krever studiekompetanse - slik som barnehagelærerutdanning, barnevernsutdanning og sykepleierutdanning, mens en rekke tradisjonelle mannsyrker krever yrkesfaglig utdanning på videregående nivå (Nielsen \& Henningsen, 2018). Det kan også tenkes at motivasjonsfaktoren spiller inn i form av at jenter kan ha en oppfatning av at de bør ha ekstra gode karakterer for å klare seg eller ta den utdanningen de ønsker (Arnesen et al., 2008; Nielsen \& Henningsen, 2018). I et slikt lys er det interessant at en rapport, riktignok fra 2006, viste at gutter som droppet ut av videregående skole, kom raskere inn i yrkeslivet sammenlignet med jenter. Det kan tyde på at en bestemt bakgrunn eller et bestemt kjønn kan være mer avgjørende for en arbeidsgiver enn et vitnemål (Grøgaard, 2006).

Et annet kritisk innspill rettes mot Stoltenbergutvalgets antakelser om at det kan være forskjell på gutter og jenters modenhetsutvikling. Når statistikk viser at prestasjonsgapet mellom gutter og jenter gradvis tettes igjen gjennom utdanningsløpet, bør det ikke være noen grunn til at jenters modenhetsutvikling settes som standard for guttenes modning (Nielsen, 2019).

Bekymringene rundt kjønnsforskjeller i elevenes prestasjoner er ikke av ny dato, de har dukket opp til stadighet de siste tiårene. En kritikk som tidligere er reist, og som er like aktuell i dag, er rettet mot den dikotomiske logikken som går ut på at når en gruppe vinner, taper en annen, eller at når noen går opp, går andre ned (Epstein et al., 1998). Det at jenter (i gjennomsnitt) presterer bedre i dag enn tidligere, innebærer ikke dermed at gutter (i gjennomsnitt) presterer dårligere enn de gjorde tidligere. Likestillingskampen i Norge og andre vestlige land har vært opptatt av hvor stor betydning skole og utdanning har for jenter (Epstein et al., 1998). Det har sannsynligvis vært en sentral drivkraft som kan ha gitt utslag både for motivasjon og skoleprestasjoner fra 1970-tallet og utover (Francis \& Skelton, 2005; Nielsen, 1981), uten at det nødvendigvis innebærer at gutters prestasjoner har endret seg.

I denne artikkelen betrakter jeg den gjentakende fortellingen av gutter som skolens tapere som et dominerende narrativ. Det åpner for spørsmålet om hvordan et slikt narrativ får makt og blir en produktiv kraft som ekskluderer eller gjør det vanskelig for andre fortellinger å komme til syne. Metoden, eller lesningen, er å anse som inspirert av Laclaus (1993) begrep om dekonstruksjon, som handler om å løse opp hegemoniske diskurser. Det er ingen metode i tradisjonell forstand, men har til hensikt å forstyrre og utfordre det som anses som sant eller naturlig. Intensjonen er å få 
frem hvilke premisser som ligger til grunn for fortellingen, hvilke konsekvenser fortellingen har og hvilke fortellinger den bidrar til å skjule. Formålet er ikke å erstatte en fortelling med en annen, men å utvide tenkningen slik at den ikke innsnevrer feltet ved å skygge for andre og større utfordringer i skolen. Stoltenbergutvalgets rapport legges til grunn fordi den utgjør en tydelig eksponent for denne fortellingen, men også andre dokumenter er aktuelle.

\section{Narrativer, diskurser og mot-narrativer}

Narrativ teori utgjør et vidt og mangfoldig felt (Chase, 2005) og benyttes i mange ulike sammenhenger, fra å omhandle livshistorier og identitet hos Ricoeur, til strukturer og handlingsgang i fiksjon som hos Propp. I denne sammenhengen forstår jeg narrativ ut fra et retorisk perspektiv. «Narrative is somebody telling somebody else, on some occasion, and for some purposes, that something happened to someone or something» (Phelan \& Rabinowitz, 2012, s. 3). Begrepet dominerende narrativ springer ut av den franske filosofen og postmodernisten Jean-Francois Lyotards begrep om grand eller master narrativ. Begrepet beskrives som totaliserende og universelle overbevisninger på metanivå, knyttet til forståelse av historiske hendelser og erfaringer så vel som sosiale og kulturelle fenomen, slik som f.eks. troen på menneskets rasjonalitet, fremskrittstankegang og ulike ideer om samfunnets iboende krefter. Grand eller master narrativ bidrar til legitimering av makt og autoritet og har performativ kraft (Lyotard, 1979). Innen narrativ psykologi definerer McLean og Syed (2015) master narrativ som "culturally shared stories that tell us about a given culture, and provide guidance for how to be a 'good' member of a culture» (s. 320). Hammack (2009) hevder at begrepet omfatter en bredere samfunnsvitenskap i form av "cultural script" eller «dominant discourse that proliferates in a society» (s. 51). Inspirert av Bambergs (2004) studier av maskulin identitet inkluderes også «the basic meaning of social categories» og "what it means to inhabit a particular social category» (Hammack \& Toolis, 2015, s. 353). Master eller dominerende narrativ, som benyttes på norsk, er dermed både performativt og normativt i form av å tilby det som oppfattes som normale erfaringer (Andrews, 2004).

Narrativer må begrepsmessig skilles fra diskurser, selv om de henger nært sammen. En diskurs forstås som en (språklig) praksis som former de sosiale objektene vi snakker om, angir hva som aksepteres som sant og fremstiller det som naturlig (Foucault, 1989). Narrativer fokuserer på organiseringen av kunnskap og betraktninger i en fortellerform, og eksemplifiserer på den måten diskursens meningsinnhold (Svarstad, 2009). Det betyr at diskursen setter premisser for fortellingen. Ulike narrativer kan knyttes til en og samme diskurs, og et narrativ kan bygge på flere diskurser.

Dominerende narrativer innebærer at andre, alternative narrativer forties eller stilles i skyggen (Andrews, 2004). Mens Lyotard (1979) vil erstatte master narrativer med små, lokale narrativer, beskriver Andrews det hun betegner som mot-narrativer (counter-narratives). Disse yter mer eller mindre implisitt motstand mot dominerende 


\section{T. S. Aasebø}

narrativer, men eksisterer i relasjon til, og leses under dekket av det dominerende narrativet. Kritiske fortellinger står dermed i et spenningsforhold til den dominerende fortellingen uten å være fullstendig i opposisjon til, eller uberørt av den. Mot-narrativet får først mening gjennom det dominerende narrativet de står i opposisjon til eller kontrer (Torre et al. referert i Andrews, 2004).

\section{Hvillet narrativ fortelles}

Søkelyset på gutters dårlige prestasjoner i skolen har blitt en seiglivet og virkningsfull fortelling om gutter som tapere, og er produsert gjennom en rekke ulike aktører. Narrativer er avhengig av at de produseres og reproduseres (Andrews, 2004). Aktører som forskere, skolepolitikere, skoleeiere, programledere, journalister og lærere har bidratt til å produsere og reprodusere fortellingen gjennom medier, utredninger og forskerrapporter allerede fra før tusenårsskiftet i Norge (se f.eks. St.meld. nr. 16 (2006-2007)). Fortellingen har også et stort omfang internasjonalt - diskusjonen om failing boys, som den kalles, har pågått i en rekke land. Arnesen et al. (2008) har beskrevet dette som travelling discourses om kjønn og utdanning, en reisende fortelling på tvers av land om hva som skal telle som fakta. Fortellingen om failing boys i skolen har føyd seg inn i diskusjoner om en omfattende maskulinitetskrise i den vestlige verden allerede på 1990-tallet. Maskulinitetskrisen ble knyttet til endringer i global økonomi som medførte en sterk reduksjon av tradisjonelle maskuline industriarbeidsplasser, og til styrkingen av kvinneres rettigheter, som samlet sett medførte tap av menns posisjoner i familie- og arbeidsliv (se f.eks. Epstein et al., 1998; Francis, 2000; Skelton, 2001; Younger et al., 1999).

Fortellingen om gutter som tapere i skolen gir seg ikke selv ut fra dokumentasjon i en rekke undersøkelser og statistikker av forskjeller mellom gutter og jenters skoleprestasjoner. Med en annen narrativ optikk kunne en helt annen fortelling sett dagens lys, en suksessfortelling: En fortelling om en skole som lykkes med det store likestillingsprosjektet, som lykkes med å kvalifisere jenter. Dette narrativet kunne handlet om en skole som i løpet av noen tiår har vært i stand til å hanskes med en stor gruppe jenter, jenter som tidligere mistet skolemotivasjonen en gang i løpet av ungdomskolen, jenter som skranglet seg gjennom gymnaset mens karakterne dalte (Nielsen, 1981), og som nå fullfører videregående med gode karakterer og tilsynelatende kan velge og vrake i høyere utdanning. En slik suksessfortelling er verken mer eller mindre sann enn taperfortellingen, men vil ha helt andre implikasjoner og konsekvenser.

Den britiske sosiologen og kjønnsforskeren Jessica Ringrose beskrev i 2007 hvordan den vedvarende utdanningspanikken rundt det som først var fokus på mislykkede gutter i England ble erstattet av en suksessfull fortelling om de flinke jentene. Suksessfortellingen baserer seg på en post-feministisk ide om jenters makt i tråd med en individualisert, nyliberalistisk tenkning. Suksessfulle jenter ble et bevis på en vellykket utdanningspolitikk i konteksten av globalisering, markedsstyring og 
$ø$ konomisk usikkerhet (Ringrose, 2007). Et slikt mot-narrativ har imidlertid ikke fått særlig fotfeste, i hvert fall ikke i Norge. Det kan være flere grunner til det. Pisa-sjokket på begynnelsen av 2000-tallet har sannsynligvis hatt en stor betydning. Christie beskriver dette retorisk som en angstbølge som gikk over landet. Den norske skolen «holder ikke mål, - veid og funnet for lett» (Christie, 2008, s. 200). Troen på at Norge hadde en av verdens beste skoler ble rystet i sine grunnvoller, slik det også skjedde i Sverige og Danmark. Fra Norge første gang deltok i den internasjonale TIMMSstudien (matematikk og naturfag) i 1995, og etter hvert i Pisa-studiene (lesing, matematikk og naturfag) og PIRLS-studiene (leseferdighet), har resultatene vist at de norske elevene ligger under det internasjonale gjennomsnittet (Björnsson \& Olsen, 2018; Kjærnsli et al., 2004). Gjennom en ny tilbakegang som inntraff i 2019 etter at resultatene i senere studier viste en viss fremgang (Björnsson \& Olsen, 2018), er det grunn til å tro at Pisa-sjokket har bidratt til krisetenkningen. Og guttene oppfattes som hovedårsaken til denne krisen.

Det er også andre mulige grunner til at suksessfortellingen om jenter ikke fikk fotfeste. Det kan være at jenters suksess ikke verdsettes på samme måte som gutters suksess. Det finnes mange eksempler på at jentenes suksess betegnes som faretruende, bl.a. gjennom påstander om at likestillingen har gått for langt (Eriksen, 2014), samtidig som jenters suksess giøres til noe mindreverdig. Suksess-narrativet forsvant sannsynligvis i det som er blitt kalt flink-pike-syndromet, et annet virkningsfullt narrativ som betrakter jenters suksess gjennom en blanding av perfeksjonisme og mindreverdighet; det siste i form av å være kjedelige og konforme (se f.eks. Madsen, 2018). Jenters suksess gis dermed en annenrangs karakter.

\section{Taperfortellingens diskursive premisser}

En og samme diskurs kan som nevnt formidles gjennom ulike narrativer. Uavhengig av om en snakker om gutter som tapere eller jenter som suksessfulle, utgår begge narrativene fra den samme diskursen om kjønn og skoleprestasjoner. Der det ene narrativet legger vekt på krise, legger det andre vekt på suksess. Premisset for begge narrativene er at gutter og jenter er to ulike størrelser med en klar distinksjon mellom hva gutter er og hva jenter er. Dette er en oppfatning som baserer seg på at det er grunnleggende biologiske forskjeller mellom kjønn som gir klare føringer for individenes utvikling. Disse oppfatningene har sitt opphav i den biologiske kunnskapsutviklingen på 1800-tallet som historisk sett har fått konsekvenser for de fleste av livets områder (Laquer, 1990). Denne kjønnsdiskursen har vært sterkt utfordret i kjønnsforskningen, først av kjønnssosialiseringsteoriene som legger vekt på samfunnsmessige strukturers betydning for kjønnsroller (se f.eks. Holter, 1971), deretter av sosialkonstruksjonistiske teorier som setter språk og diskurser i fokus (se f.eks. Burr, 2003; Butler, 1990). Det er neppe noen som ser bort fra at det er ulikheter innad i kjønnskategoriene i dag, eller at kultur og språk har innvirkning på kjønn. Stoltenbergutvalget understreker også at det er snakk om 


\section{T. S. Aasebø}

gjennomsnittsforskjeller (NOU 2019: 3), med det får likevel ingen konsekvenser for to-kjønnstenkningen utvalget legger til grunn. Forskjellen mellom distribusjon, dvs. fordeling, som er basert på gjennomsnitt, og distinksjon, som er basert på en todeling av kjønn (Nielsen, 2014), flyter over i hverandre og bidrar kun til en modifisert utgave av den dikotomiske kjønnsdiskursen. Kjønnsforskningen som baserer seg på sosiale, konstruksjonistiske og diskursive forståelser innebærer et kjønnsperspektiv som er langt mer mangfoldig enn to-kjønnstenkningen: Kjønn gjøres på mange måter, og variasjonene innen et kjønn kan være større enn variasjonene på tvers av kjønn. Slike perspektiver undersøker hvordan forestillinger av kjønn formidles gjennom språk og forventninger.

Kjønnsforskningen som forstår kjønn som sosiale konstruksjoner, som er opptatt av hvordan kjønn kulturelt konstrueres, og som er basert på teoriutvikling som har pågått i kjønnsforskningsmiljøer i Norge og resten av den vestlige verden de siste femti årene, utelates helt i Stoltenbergutvalgets rapport. Det dreier seg om teorier som har endret forestillinger om selve forskningsobjektet kjønn. ${ }^{1}$ og som rokker ved de etablerte doxa-forestillinger (Mortensen et al., 2008), det som fremstår som naturlig. Dermed har utvalget heller ikke lånt øre til forskning som viser hvordan institusjoner og sosiale agenter produserer kjønn. Det gjelder særlig forskning som er opptatt av hvordan femininitet og maskulinitet, dvs. de rådende ideene om hva jente og gutt betyr, konstrueres til enhver tid og i ulike kontekster (se f.eks. Butler, 1990; Connell, 1995; 2000; Davies, 2003; Frosh et al., 2002; Lorentzen, 2006). Det innebærer forskning ut fra et agency-perspektiv, et perspektiv som tilkjenner individet/ barnet status som sosial aktør som både skaper og skapes av omgivelsene (James et al., 1998). Denne forskningen viser hvordan kjønn kan forstås som individets aktive orientering mot egen kjønnsgruppe (se f.eks. begrepet "grensemarkering» $\mathrm{i}$ Nielsen, 2011), istedenfor å være et uttrykk for individenes bestemte kognitive, emosjonelle og sosiale egenskaper eller utviklingsnivå. Det innebærer forskning som viser hva som teller for å være akseptert som gutt eller jente i ulike kontekster (Francis et al., 2009; Haavind, 2003; Swain, 2004), som kan ha betydning for hvordan enkelte forholder seg til skolen. Flere har vist hvordan popularitet og anerkjennelse blant en del gutter ofte baserer seg mer på å score mål i fotball eller være en racer i dataspill, enn å være skoleflink og lære bokstavene i en fei (se f.eks. Frosh et al., 2002; Swain, 2004, Aasebø, 2011). På samme måte var det å være flink på skolen heller ikke et trumfkort for jenter i første halvdel av 1900-tallet.

Diskurser opprettholdes gjennom sosiale praksiser (Butler, 1990). Forskning anses som en sosial praksis. Stoltenbergutvalget har i hovedsak benyttet evidensbasert forskning for å finne årsaker til kjønnsforskjellene i skolen. I det nye kunnskapssystemet som skal bygges opp for videre kunnskapsinnhenting, er evidensbasert forskning metoden som foreskrives. I presentasjonen av denne forskningen heter det at

\footnotetext{
${ }^{1}$ Det er selvsagt snakk om et spenningsfelt av teorier og perspektiver, men som har det til felles at de stiller spørsmål ved måten kjønn fremstilles på i en kultur.
} 
utvalget [har] valgt å prioritere empiriske studier som kan identifisere årsaker og effekter. I forskningslitteraturen regnes ofte eksperimenter som gullstandarden for å identifisere årsaker og effekter av tiltak. (NOU 2019: 3, s. 73)

Stoltenbergutvalgets evidensbaserte kunnskapssyn er grundig formulert og kritisert i en artikkel av Nielsen \& Malterud (2019). Her vil jeg understreke den konstituerende gjensidigheten mellom den dikotomiske kjønnsforståelsen og evidensbasert forskning.

Evidensforskning, som baserer seg på hva som virker inn eller har effekt på gitte størrelsene, er både en logisk følge av et dikotomisk kjønnsperspektiv, og opprettholder samtidig dette perspektivet ved å produsere og reprodusere forskjellstenkningen. Og når den eksisterende forskningen utvalget har sett på, som i hovedsak er evidensbasert, ikke resulterer i klare svar (NOU 2019:3, s. 13), foreskrives ytterlige evidensbasert forskning.

Et perspektiv på kjønn hvor kjønnede betydninger kan være todelte, men uten at en tar det kjønnede ved personer for gitt (Haavind, 2001), passer åpenbart ikke inn i metoder basert på årsak og virkning. Når Stoltenbergutvalget sporadisk referer til slik forskning får det ingen konsekvenser for overveielser, tiltak eller videre forskning. For eksempel sier utvalget at «kunnskapsgrunnlaget viser at forventninger til læring spiller en viktig rolle for elevenes utbytte av undervisningen, og at gutter møtes med lavere forventninger til læring i skolen enn jenter» (NOU 2019: 3, s. 197). Det kan tenkes at dette er sakens kjerne. Dette er et perspektiv som antyder at forventningene som stilles av lærere eller foreldre er kjønnede, og at de kjønnede forventningene kan få betydning for gutter og jenters fortolkninger av seg selv. Å forfølge dette sporet fordrer kvalitative studier i klasserom over tid, og kan ikke enkelt innpasses $i$ et evidensparadigme. Dermed inngår heller ikke denne type forskning i beskrivelsen av ytterligere kunnskapsbehov, som isteden domineres av forslag om opprettelse av et nasjonalt register for forløpsdata i tillegg til ytterligere kartlegging og testing.

Det er paradoksalt at desto mer det snakkes om jenter som flinke og gutter som mindre flinke, jo klarere formuleres forventninger til dem om nettopp det, underforstått at skolen ikke er for gutter. Dermed bidrar både taperfortellingen og suksessfortellingen som springer ut av den to-kjønnede tenkningen, til at kjønnsforskjellene konsoliderer og forsterker de skjevhetene en vil ha bukt med.

\section{De usynlige fortellingene}

Et annet narrativ som stilles i skyggen av det dominerende narrativet om gutter som tapere er fortellingen om sosial ulikhet og sosiale forskjeller basert på foreldres sosiale og økonomiske ressurser, definert som sosial klasse. I de fleste undersøkelser operasjonaliseres dette i dag som foreldrenes utdanningsnivå, i noen sammenhenger også familiens økonomiske og kulturelle kapital (Bakken et al., 2016). Dette motnarrativet kan anses slik Andrews (2004) beskriver som en kritisk fortelling som står 


\section{T. S. Aasebø}

i et spenningsforhold til fortellingen om gutter som tapere, uten å være fullstendig i opposisjon til den.

Ulikheter knyttet til sosial klasse eller sosial bakgrunn har vært ett av de mest fundamentale temaene innen utdanningssosiologien (Reay, 2010). Etter at Gudmund Hernes (1974) skrev om ulikhetenes reproduksjon i Norge på 1970-tallet, er det jevnlig påvist gjennom statistikk og surveyundersøkelser hvordan sosial bakgrunn slår ut på elevenes karakterer, utdanningsforløp, drop out osv. (se f.eks. Bakken, 2004; Bakken et al. 2008; Hansen, 2005; Heggen et al., 2014; Iversen, 2014; Markussen, 2010). Og selv om dataene viser kjønnsforskjeller i prestasjoner for alle elevgruppene basert på foreldrenes utdanningsnivå, er forskjellene basert på sosial bakgrunn ifølge Bakken et al. (2008) større. Stoltenbergutvalgets rapport presenterer også undersøkelser som viser forskjeller basert på foreldrenes utdanningsnivå (se NOU 2019: 3, s. 49), men uten at det får utfordre det dominerende narrativet. Disse vedvarende sosiale forskjellene blir sjelden et tungt anliggende i utdanningspolitiske debatter eller utredninger, på tross av at skolens samfunnsmandat helt siden enhetsskolen ble innført, har vært å bidra til å utjevne sosiale forskjeller. Behovet for å motvirke og utjevne sosiale forskjeller stod sentralt i stortingsmeldingen «... og ingen stod igjen» (St.meld. nr. 16 (2006-2007)) og uttrykkes fremdeles ifølge Ludvigsen-utvalget (NOU 2014: 7) i utdanningspolitiske dokumenter gjennom begrepet fellesskolen.

Både dominerende narrativer og mot-narrativer gir perspektiver som ikke nødvendigvis utelukker hverandre, men som kan gi rom for mangfold og nyanser. Det er også det en rekke studier gjør når de kobler kategorier som kjønn, sosial klasse, minoritetsbakgrunn osv. For eksempel beskriver Phoenix at skolens forventninger ikke lett harmonerer med mange arbeiderklasse- og minoritetsgutters subjektiveringsprosess og den lokale praksis hvor disse guttene produserer maskulinitet. Ikke alle gutter er i en posisjon hvor de fritt kan velge å opptre på måter som kan forbedre deres fremtidige kvalifikasjoner. Kjønn opptrer altså ikke isolert, men inntar samtidig posisjoner som sosial klasse, farge og etnisitet (Phoenix, 2003). Slik beskrives kjønn også i Walkerdine et al. sin (2001) longitudinelle studie av engelske arbeiderklasse- og middelklassejenter i grunnskolen: Mens middelklassejentene fikk hjelp og støtte for å oppnå forventningene om å være flinke, manglet mange arbeiderklassejenter ideer om hvordan de kunne oppnå mål, ønsker eller fantasier de hadde om fremtiden. I begge disse studiene forstås subjektivitet som noe som produseres i en kompleks sammenheng $i$ en sosial og lokal kontekst. Det å bevege seg på tvers av slike kontekster kan være både rotløst og skremmende. En slik forståelse står i kontrast til konvensjonelle forklaringer som ofte benyttes når sosial bakgrunn skal forklare manglende skoleprestasjoner, nemlig disse elevenes manglende motivasjon for skole og utdanning. Walkerdine tar sterk avstand fra påstander om arbeiderklassebarnas manglende motivasjon:

Far from this, I suggest that such students may not lack a way of fantasising a set of desires for the future, but are not well supported in education to mobilise these into an imagination which can be acted upon. (Walkerdine, 2011, s. 256) 
Koblingen av ulike sosiale kategorier, som kjønn, sosial klasse og en rekke andre kategorier som etnisitet, hudfarge osv., forstås med begrepet interseksjonalitet og gir uttrykk for hvordan de ulike kategoriene konstruerer hverandre og inngår i ulike maktforhold (Orupabo, 2014). Flere har imidlertid kritisert begrepet for å være fragmenterende og miste sin kritiske funksjon (Lykke, 2005). Samtidig kan bruken av begrepet rammes av den samme kritikken som de dikotomiske kjønnskategoriene: hvis kategoriene betraktes som strukturerende, opprettholdes også den dikotomiske kjønnsdiskursen. Orupabo (2014) foreslår heller at interseksjonalitetsbegrepet må forstås som et dynamisk begrep som er bevegelig på aksen mellom struktur (strukturorientert perspektiv) og kontekst (poststrukturalistisk perspektiv). Det innebærer å løse opp motsetningen mellom å forstå kategorier (kjønn) som grunnleggende differensieringsform på den ene siden, og som produkter av sosial informasjon som utføres situert og kontekstuelt på den andre, hvor interseksjonalitet både kan opptre som subjektive praksiser og som grunnleggende sosiale forhold som eksisterer uavhengig av individuelle manifestasjoner (Orupabo, 2014, s. 346-347). Det betyr også å ta høyde for at kjønn er levd erfaring, men det fordrer samtidig en varsom og kontinuerlig avveiing av når det er mest relevant å undersøke hvordan kjønn konstrueres i en kontekst og når det er mer relevant å undersøke resultatet av disse kjønnskonstruksjonene. Samtidig kan insistering på kontekst bidra til å løfte blikket til det som er problemskapende, istedenfor å sikte inn problemfulle grupper gjennom en stadig mer finmasket beskrivelse av elevgrupper som ikke oppfyller skolens krav. Istedenfor å posisjonere bestemte elevgrupper gjennom taperfortellinger, kan fokuset flyttes til hvordan og på hvilke måter skolen blir produsent av sosiale ulikheter.

\section{Taperfortellinger og utdanningsparadokset}

Når elevenes prestasjoner ut fra deres sosiale bakgrunn er tema, har det bidratt til kritikk av skolesystemet, særlig skolens pedagogiske innhold og kultur. Bourdieu representerer et slikt perspektiv ved å vise hvordan utdanningssystemet opprettholder og reproduserer samfunnets sosiale orden gjennom verdsetting av en type kulturell kapital (Bourdieu \& Passeron, 1977). Det samme gjør Bernstein, som har utviklet begrepene klassifisering og innramming for å beskrive undervisning som synlig og usynlig pedagogikk. Synlig pedagogikk har synlig, dvs. sterk klassifikasjon (undervisningens hva) og innramming (interaksjonskontroll). Usynlig pedagogikk har mindre synlig pedagogikk, dvs. svak klassifikasjon og innramming. Den usynlige pedagogikken ble kritisert for å gi fordeler til den utdannede middelklassens barn fordi de var bedre utrustet til å avkode denne pedagogikkens suksesskriterier (Bernstein, 2000; Jensen, 2019). Diskusjonene rundt fortellingen om gutter som tapere har også i en periode til en viss grad angrepet systemnivået og dreid seg om argumenter om at skolen er feminisert gjennom overrepresentasjon av kvinnelige lærere og rådende matriarkalske verdier i skolens arbeidsformer (stillesitting, tålmodighet), samværsformer (samarbeid, kommunikasjon, verbalisering) og autoritetsformer 


\section{T. S. Aasebø}

(subtile) (se f.eks. Bredesen, 2004; Nordahl, 2007). ${ }^{2}$ Stoltenbergutvalget tar imidlertid ikke opp slike perspektiv. De konkrete tiltakene som foreslås går ut på å tilpasse guttene bedre til skolen gjennom tidlig innsats, ekstra innsats, tilpasset innsats og fleksibel skolestart. ${ }^{3}$

Mange forskere adresserer gjennom kvalitative studier den økende tendensen til individualisering av undervisning og læringsprosesser. «New public management» og den nyliberalistiske tenkningen som følger av det arter seg ifølge Phoenix (2003) som

continually changing the self, making informed choices, engaging in competition, and taking the chances offered by the marked and the government to consume and take advantage of the provisions of lifelong learning and so forth. (s. 229)

Markedsstyring og nyliberalistisk tenkning nedfeller seg i stadig mer individualisert undervisning og krav til elevenes ansvar og selvdisiplin, og konstruerer forestillinger om det autonome og individuelt ansvarlige mennesket, en forestilling som også bidrar til konstruksjon av selv: Subjekter forstår seg selv som ansvarlige for å skape sitt eget liv. Phoenix (2003) argumenterer for at ikke alle elever er i stand til å benytte seg av mulighetene som nyliberalismen foreskriver. Internasjonalt fokus på «improving children's achievement but also on helping teachers become more professionally competent through school-based evaluations and action research» (Popkewitz, 2000, s. 18), manifesterer seg gjennom skolens deltakelse i internasjonale tester (PISA; PIRLS; TIMMS), i vektleggingen av kompetansemål (output) (Sivesind, 2013), i økningen av individuelt arbeid fremfor fellesundervisning (Bachmann et al., 2010; Dalland \& Klette, 2016; Haug, 2012; Karseth \& Engelsen, 2007) og i individuell ansvarliggjøring av deltakelse og læring. Det siste gis det beskrivelser av i flere etnografiske studier fra videregående skoler. Bertelsens (2010) studie viser hvordan individualiseringen materialiserer seg i et nytt åpent gymnasbygg i Danmark, som legger grunnlag for nye elevposisjoner. Eriksen (2017) viser gjennom studier av en norsk videregående skole, karakterisert som en baseskole med fravær av grenser og autorativ orden, hvordan undervisningen krever selvdreven læring og selvdisiplinerte elever. Her fremstår minoritetsjenter som opposisjonelle bråkmakere i klasserommet fordi de blir frustrerte av og ikke kan hanskes med "manglende grenser og krav om selvdisiplin» (Eriksen, 2014, s. 153). Steno (2016) har studert hvordan de individualiserte læringsløpene som dansk yrkesutdanning legger til rette for, inneholder en rekke motsigelser og dobbeltheter for utsatte gutter og jenter.

De sosiale forskjellene har økt etter innføringen av Kunnskapsløftet (Bakken, 2010). Dagens utdanningspolitikk rommer her et paradoks. På den ene siden

\footnotetext{
${ }^{2}$ Disse argumentene har vært ført med langt større styrke i Danmark (se f.eks. Nordahl, 1996), men har også vært fremtredende i norske debatter og kommentarfelt.

${ }^{3}$ Forslaget om fleksibel skolestart fikk imidlertid ikke flertall i utvalget, men er like fullt lansert som et forslag i etterkant av Stoltenbergutvalgets rapport.
} 
formidles det en retorikk om likhet og sosial utjevning, på den andre siden får elevene et stadig mer personlig ansvar for å lykkes eller mislykkes (Reay, 2010) Ifølge Macedo (2013) er equity i global utdanningspolitikk etter hvert forvandlet til quality (kvalitet), forstått som utdanning for demokrati, medborgerskap og deltakelse på et globalt og konkurranseorientert arbeidsmarked. Målestokken er stor-skala testing av elevenes prestasjoner, ferdigheter og kompetanser. Testing og utdanningspolitikk er bygd på premisset om at rettferdighet er mulig og ønskelig, mens internasjonal forskning på nasjonale tester imidlertid viser en motsatt effekt av det en ønsker å oppnå med dem (Knapp \& Hopmann, 2017, s. 23). Dermed fremstår motsetningen mellom rettferdighet og differensiering som en av de største utdanningspolitiske utfordringer noen gang.

Acknowledging the constitutive outside, the "differentiation", in the symbolic system that defines equity, quality or inclusive citizenship, does not eliminate it like an antagonistic cut; on the contrary, it keeps it like the ghost that clarifies the impossibility of equity. (Macedo, 2013, s. 34)

Utdanningspolitikken anses dermed som kontradiktorisk, ute av stand til å hanskes med sosiale ulikheter eller yte rettferdighet overfor alle elever. Desto mer vekt det legges på testing av elevens teoretiske prestasjoner, jo større press for alle vanskeligstilte elever, og dermed ytterligere segregering og ulikheter mellom elevene (Macedo, 2013).

Det at skolen bidrar til å reprodusere og forsterke ulikheter istedenfor å utjevne dem, rokker ved skolens legitimitet på en langt mer grunnleggende måte enn hva narrativet om gutter som skolens tapere gjør. Kjønnsforskjellene fremstår i det lange løp mer håndterlige. Og når de ikke lar seg forklare ut fra den evidensbaserte kunnskapen en har, kan en alltid argumentere med at kunnskapsgrunnlaget er for dårlig, og foreslå ytterligere forskning av samme type: Mer registrering i form av nasjonale registerdata, mer kartlegging og mer testing. Men de store og økende sosiale ulikhetene løses ikke med mer evidensbasert kunnskap og testing. Det fordrer en langt større diskusjon om hva skolen skal være, om innhold og organisering, teori og praksis og avveiingen mellom danning og kvalifisering, diskusjoner som har vært en del av pedagogikk-disiplinen siden dens opprinnelse, og som kontinuerlig er et anliggende for praktikerne som daglig møter elevene i skolen.

\section{Forfatterbiografi}

Turid Skarre Aasebø er professor i pedagogikk ved Universitetet i Agder, og forsker på temaer som kjønn, elevkulturer, allmenndidaktikk og mangfold i undervisningen gjennom etnografi og klasseromsforskning. Hun leder forskningsgruppen «allmenndidaktikk og utdanningspolitikk» og har bl.a. gitt ut bøker som Kunnskapsforhandlinger $i$ klasserommet og artikler om «anti-schoolness» og «teaching in the age of accountability». 


\section{T. S. Aasebø}

\section{Referanser}

Andrews, M. (2004). Opening to the original contributions: Counter-narratives and the power to oppose. I M. Andrews \& M. G. W. Bamberg (Red.), Considering counter narratives: Narrating, resisting, making sense (s. 1-6). John Benjamins Publishing Co.

Arnesen, A.-L., Lahelma, E. \& Öhrn, E. (2008). Travelling discourses on gender and education: The case of boys' underachievement. Nordisk pedagogik, 28(1), 1-14. https://www.idunn.no/np/2008/01/travelling discourses_on_gender_and_education_-_the_case_of_boys_underachievement

Bachmann, K. E., Haug, P. \& Myklebust, R. (2010). Med rett til å prestere. I E. Elstad \& K. Sivesind (Red.), PISA: Sannheten om skolen? (s. 298-317). Universitetsforlaget.

Bakken, A. (2004). Økt sosial ulikhet i skolen? Tidsskrift for ungdomsforskning, 4(1), 83-91. https://journals. oslomet.no/index.php/ungdomsforskning/article/view/1142

Bakken, A. (2010). Prestasjonsforskjeller $i$ kunnskapsløftets første år: Kjønn, minoritetsstatus og foreldres utdanning (NOVA-rapport 9/10). Fagarkivet. http://hdl.handle.net/20.500.12199/5005

Bakken, A., Borg, E., Hegna, K. \& Backe-Hansen, E. (2008). Er det skolens skyld?En kunnskapsoversikt om skolens bidrag til kjønnsforskjeller $i$ skoleprestasjoner (NOVA-rapport Fagarkivet. http://hdl.handle.net/ 20.5004/08).12199/4957

Bakken, A., Frøyland, L. R. \& Sletten, M. A. (2016). Sosiale forskjeller i unges liv: Hva sier Ungdata-undersøkelsene? (NOVA-rapport 3/16). Fagarkivet. http://hdl.handle.net/20.500.12199/5103

Bamberg, M. (2004). Form and functions of «slut bashing» in male identity constructions in 15-year-olds. Human Development, 47(6), 331-353. https://doi.org/10.1159/000081036

Bernstein, B. (2000). Pedagogy, symbolic control and identity: Theory, research, critique. Rowman \& Littlefield.

Bertelsen, E. (2010). Når glas beskytter - om eksponering og synlighet i nyt dansk gymnasbyggeri. Dansk pedagogisk tidsskrift, 3, 44-53.

Björnsson, J. K. \& Olsen, R. V. (2018). Tjue år med TIMSS og PISA i Norge. Scandinavian University Press / Universitetsforlaget.

Bourdieu, P. \& Passeron, J.-C. (1977). Reproduction in education, society and culture. Sage.

Bredesen, O. (2004). Nye gutter og jenter - en ny pedagogikk? Cappelen akademisk forlag.

Burr, V. (2003). Social constructionism. Routledge.

Butler, J. (1990). Gender trouble: Feminism and the subversion of identity. Routledge.

Chase, S. E. (2005). Narrative inquiry: Multiple lenses, approaches, voices. I N. K. Denzin \& Y. S. Lincoln (Red.), The Sage handbook of qualitative research (3. utg., s. 651-679). Sage Publications.

Christie, N. (2008). I skyggen av Pisa. Nytt norsk tidsskrift, 25(2), 200-207. https://www.idunn.no/nnt/2008/02/ debatt_i_skyggen_av_pisa

Connell, R.W. (1995). Masculinities. Polity Press.

Connell, R. W. (2000). The men and the boys. University of California Press.

Dalland, C. P. \& Klette, K. (2016). Individual teaching methods: Work plans as a tool for promoting selfregulated learning in lower secondary classrooms? Education Inquiry, 7(4), 381-404. https://doi. org/10.3402/edui.v7.28249

Davies, B. (2003). Hur flickor och pojkar gör kön. Liber.

Epstein, D., Elwood, J., Hey, V. \& Mow, J. (1998). Failing boys?Issues in gender and achievement. Open University Press.

Eriksen, I. (2014). Tøffe krav og tøffe jenter: Kjønn og etnsitet i videregående skole. I H. B. Nielsen (Red.), Forskjeller $i$ klassen: Nye perspektiver på kjønn, klasse og etnisitet $i$ skolen (s. 152-167). Universitetsforlaget.

Eriksen, I. M. (2017). De andres skole: Gruppedannelse og utenforskap $i$ den flerkulturelle skolen. Gyldendal Akademisk.

Foucault, M. (1989). The archaeology of knowledge. Routledge.

Francis, B. (2000). Boys, girls and achievement: Addressing the classroom issues. Routledge Falmer.

Francis, B. \& Skelton, C. (2005). Reassessing gender and achievement: Questioning contemporary key debates. Routledge.

Francis, B., Skelton, C. \& Read, B. (2009). The simultanous production of education achievement and popularity: How do some pupils accomplish it? British Educational Research fournal, 36(2), 317-340. https://doi.org/10.1080/01411920902919265

Frosh, S., Phoenix, A. \& Pattman, R. (2002). Young masculinities. Understanding boys in contemporary society. Palgrave. 


\section{Fortellinger om gutters krise, jenters fremgang og skolens utfordringer med sosiale ulikheter}

Grøgaard, J. B. (2006). Yrkesutdannede ungdommers overgang til arbeid: Jevne overganger og midlertidige avbrudd. I J. B. Grøgaard (Red.), Kunnskapssamfunnet tar form (s. 225-263). Cappelen akademisk forlag.

Hammack, P. L. (2009). Exploring the Reproduction of Conflict Through Narrative: Israeli Youth Motivated to Participate in a Coexistence Program. Peace and Conflict, 15, 49-74. https://psycnet.apa.org/ fulltext/2010-12089-003.pdf

Hammack, P. L. \& Toolis, E. E. (2015). Putting the social into personal identity: The master narrative as root metaphor for psychological and developmental science. Human Development, 58(6), 350-364. https://doi. org/10.1159/000446054

Hansen, M. N. (2005). Utdanning og ulikhet - valg, prestasjoner og sosiale settinger. Tidsskrift for samfunnsforskning, 46(2), 133-157. https://www.idunn.no/tfs/2005/02/utdanning_og_ulikhet_valg_ prestasjoner_og_sosiale_settinger

Haug, P. (2012). Aktivitetane i klasseromma. I P. Haug (Red.), Kvalitet i oppleringa:Arbeid i grunnskolen observert og vurdert (s. 58-76). Samlaget.

Heggen, K., Helland, H. \& Lauglo, J. (2014). Utdanningssosiologi. Sosiologisk tidsskrift, 22(2), 221-224. https:// www.idunn.no/st/2014/02/kaare_heggen_haavard_helland_og_jon_lauglo_utdanningssosiol

Hernes, G. (1974). Om ulikhetens reproduksjon: Hvilken rolle spiller skolen? I M. S. Mortensen (Red.), I forskningens lys (s. 231-251). Universitetsforlaget.

Holter, H. (1971). Sex roles and social change. Acta Sociologica, 14(2), 2-12. https://doi.org/10.1177/ 000169937101400202

Haavind, H. (2001). På jakt etter kjønnede betydninger. I H. Haavind (Red.), Kjønn og fortolkende metode: Metodiske muligheter $i$ kvalitativ forskning. Gyldendal Akademisk.

Haavind, H. (2003). Masculinity by rule-breaking: Cultural contestations in the transitional move from being a child to being a young male. Nordic fournal of Feminist and Gender Research, 11(2), 89-100. https://doi. org/10.1080/08038740310002941

Iversen, R. (2014). Utdanning og ulikhet i Norge: Opprettholder vi en tradisjonell lagdelingsstruktur, eller beveger vi oss mot en meritokratisk klassestruktur? Et historisk tilbakeblikk. Norsk pedagogisk tidsskrift, 98(2), 105114. https://www.idunn.no/npt/2014/02/utdanning_og_ulikhet_i_norge_-_opprettholder_vi_en_tradisjo

James, A., Jenks, C. \& Prout, A. (1998). Theorizing childhood. Polity Press.

Jensen, A. R. (2019). Innvielse til lcereryrket: En analyse av praksislcereres veiledningssamtaler. Cappelen Damm Akademisk. https://doi.org/10.23865/noasp.70

Karseth, B. \& Engelsen, B. U. (2007). Læreplan for Kunnskapsløftet - et endret kunnskapssyn? Norsk pedagogisk tidsskrift, 91(5), 404-415. https:/www.idunn.no/npt/2007/05/lereplan_for_kunnskapsloftet_-_et_endret_ kunnskapssyn

Kjærnsli, M., Lie, S., Olsen, R. V., Roe, A. \& Turmo, A. (2004). Rett spor eller ville veier? Norske elevers prestasjoner i matematikk, naturfag og lesing $i$ PISA 2003. Universitetsforlaget.

Knapp, M. \& Hopmann, S. (2017). School leadership as gap management: Curriculum traditions, changing evaluation parameters, and school leadership pathways. I M. Uljens \& R. M. Ylimaki (Red.), Bridging educational leadership, curriculum theory and Didaktik: Non-affirmative theory of education (s. 229-256). Springer International Publishing. https://doi.org/10.1007/978-3-319-58650-2_6

Laclau, E. (1993). Power and representation. I M. Poster (Red.), Politics, theory and contemporary culture (s. 77-296). Columbia University Press.

Laquer, T. (1990). Making sex: Body and gender from the Greeks to Freud. Harvard University Press.

Lorentzen, J. (2006). Forskning på menn og makuliniteter. I J. Lorentzen \&W. Mühleisen (Red.), Kjønnsforskning: En grunnbok (s. 121-135). Universitetsforlaget.

Lykke, N. (2005). Nya perspektiv på intersektionalitet. Kvinnovetenskaplig tidskrift, 2/3, 7-17. http://ojs.ub.gu. se/ojs/index.php/tgv/article/viewFile/2332/2086

Lyotard, J.-F. (1979). The postmodern condition: A report on knowledge. University of Minnesota Press.

Macedo, E. (2013). Equity and difference in centralized policy. Fournal of Curriculum Studies, 45(1), 28-38. https://doi.org/10.1080/00220272.2012.754947

McLean, K. C. \& Syed, M. (2015). Personal, master, and alternative narratives: An integrative framework for understanding identity development in context. Human Development, 58(6), 318-349. https://doi. org/10.1159/000445817

Madsen, O. J. (2018). Generasjon prestasjon: Hva er det som feiler oss? Universitetsforlaget. 


\section{T. S. Aasebø}

Markussen, E. (2010). Valg og gjennomføring av videregående opplæring før Kunnskapsløftet. Acta Didactica Norge, 4(1), 1-18. https://doi.org/10.5617/adno.1057

Mortensen, E., Egeland, C., Gressgård, R., Holst, C., Jegerstedt, K., Rosland, S. \& Sampson, K. (2008). Kjønnsteori. Gyldendal Akademisk.

Nielsen, H. B. (1981). Små piger, søde piger, stille piger - om pigeliv og pigesosialisering. Sosiologi $i$ dag, 3/4, 25-55. http://ojs.novus.no/index.php/SID/article/view/983/974

Nielsen, H. B. (2011). Kjønn i klasserommet. I M. B. Postholm \& E. Munthe (Red.), Elevmangfold i skolen 1-7 (s. 179-195). Høyskoleforlaget.

Nielsen, H. B. (2014). Forskjeller $i$ klassen: Nye perspektiver på kjønn, klasse og etnisitet $i$ skolen. Universitetsforlaget.

Nielsen, H. B. (2019). Tidlig innsats - for å kompensere for kjønn? Barnehagefolk, 36(1), 38-43. https://www. stk.uio.no/om/aktuelt/i-media/2019/2019-barnehagefolk.pdf

Nielsen, H. B. \& Henningsen, I. (2018). Guttepanikk og jentepress - paradokser og kunnskapskrise. Tidsskrift for kjønnsforskning, 42(1-2), 6-28. https://doi.org/10.18261/issn.1891-1781-2018-01-02-02

Nielsen, H. B. \& Malterud, K. (2019). Kunnskap for politikk og praksis? En analyse av Stoltenbergutvalgets kunnskapssyn. Tidsskrift for samfunnsforskning, 60(3), 274-284. https://doi.org/10.18261/issn.1504291X-2019-03-04

Nordahl, B. (1996). Tarzan i damejunglen. Forlaget Nielsens.

Nordahl, T. (2007). Gutter og jenters situasjon og laring $i$ skolen. Høgskolen i Hedmark.

NOU 2014: 7. (2014). Elevenes lcring i fremtidens skole: Et kunnskapsgrunnlag. Kunnskapsdepartementet. https:// www.regjeringen.no/no/dokumenter/NOU-2014-7/id766593/

NOU 2019: 3. (2019). Nye sjanser - bedre laring: Kjønnsforskjeller $i$ skoleprestasjoner og utdanningsløp. Kunnskapsdepartementet. https:/www.regjeringen.no/no/dokumenter/nou-2019-3/id2627718/

Orupabo, J. (2014). Interseksjonalitet i praksis: Utfordringer med å anvende et interseksjonalitetsperspektiv i empirisk forskning. Sosiologisk tidsskrift, 22(4), 329-351. https://www.idunn.no/st/2014/04/interseksjonalitet_ i_praksis_utfordringer_med_aa_anvende_e

Phelan, J. \& Rabinowitz, P. J. (2012). Narrative as rhetoric. I D. Herman, J. Phelan, P. J. Rabionowitz, B. Richardson \& R. Warhol (Red.), Narrative theory: Core concepts and critical debates (s. 3-8). Ohio State University Press.

Phoenix, A. (2003). Neoliberalism and masculinity: Racialization and the contradictions of schooling for 11- to 14-year-olds. Youth \& Society, 36(2), 227-246. https://doi.org/10.1177/0044118X04268377

Popkewitz, T. S. (2000). The denial of change in educational change: Systems of ideas in the construction of national policy and evaluation. Educational Researcher, 29(1), 17-29.

Reay, D. (2010). Sociology, social class and education I M. W. Apple, S. J. Ball \& L. A. Gandin (Red.), The Routledge international handbook of the sociology of education (s. 396-404). Routledge. https://doi.org/ $10.4324 / 9780203863701$

Ringrose, J. (2007). Successful girls? Complicating post-feminist, neoliberal discourses of educational achievement and gender equality. Gender and education, 19(4), 471-489. https://doi.org/10.1080/ 09540250701442666

Sivesind, K. (2013). Læreplanene i Kunnskapsløftet: Et internasjonalt sammenliknende perspektiv. Norsk pedagogisk tidsskrift, 97(6), 370-387. https://www.idunn.no/npt/2013/06/laereplanene_i_kunnskapsloeftet_ et_internasjonaltsammenlikne

Skelton, C. (2001). Schooling the boys: Masculinities and primary education. Open University Press.

St.meld. nr. 16 (2006-2007). ... og ingen sto igjen. Tidlig innsats for livslang laring. Kunnskapsdepartementet. https:/www.regjeringen.no/no/dokumenter/stmeld-nr-16-2006-2007-/id441395/

Steno, A. M. (2016). Om sociale fællesskabers svære betingelser på EUD. Dansk Pcedagogisk Tidsskrift, (4), 40-50.

Svarstad, H. (2009). Narrativitetens sosiologi. Sosiologi $i$ dag, 39(4), 29-56. http://ojs.novus.no/index.php/SID/ article/view/1014/1005

Swain, J. (2004). The resources and strategies that 10-11-year-old boys use to construct masculinities in the school setting. British Educational Research fournal, 30(1), 167-185. https://doi.org/10.1080/0141192031 0001630017

Walkerdine, V. (2011). Neoliberalism, working-class subjects and higher education. Contemporary Social Science, 6(2), 255-271. https://doi.org/10.1080/21582041.2011.580621 
Fortellinger om gutters krise, jenters fremgang og skolens utfordringer med sosiale ulikheter

Walkerdine, V., Lucey, H. \& Melody, J. (2001). Growing up girl: Psychosocial explorations of gender and class. Palgrave.

Younger, M., Warrington, M. \& Williams, J. (1999). The gender gap and classroom interactions: Reality as rhetoric? British Fournal of Sociology of Education, 20(3), 325-341. https://doi.org/10.1080/01425699995290

Aasebø, T. (2011). Anti-schoolness in context: The tension between the youth project and the qualifications project. Social Psychology of Education, 14, 503-518. https://doi.org/10.1007/s11218-011-9153-3 